\title{
Evaluation of Sweetpotato (Ipomoea batatas (L.) Lam.) Genotypes for Resistance to Alternaria Leaf Petiole and Stem Blight (Alternaria spp.) in Uganda
}

\author{
Godfrey Sseruwu ${ }^{1}$, Mary Nanyanzi ${ }^{2}$, Agnes Alajo $^{3}$, George Kituuka $^{1} \&$ Ian Benywanira $^{1}$ \\ ${ }^{1}$ Mukono Zonal Agricultural Research and Development Institute, Mukono, Uganda \\ ${ }^{2}$ Department of Agricultural and Biological Sciences, Faculty of Science and Technology, Uganda Christian \\ University, Mukono, Uganda \\ ${ }^{3}$ Root Crops Research Programme, National Crops Resources Research Institute, Namulonge, Kampala, Uganda \\ Correspondence: Godfrey Sseruwu, Mukono Zonal Agricultural Research and Development Institute, P.O. Box \\ 164, Mukono, Uganda. Tel: 256-414-290-232. E-mail: gsseruwu@naro.go.ug
}

Received: July 29, 2020

Accepted: August 31, $2020 \quad$ Online Published: September 15, 2020

doi:10.5539/jas.v12n10p263

URL: https://doi.org/10.5539/jas.v12n10p263

This research was financed by the Alliance for a Green Revolution in Africa (AGRA) and the Agricultural Technology and Agribusiness Advisory Services (ATAAS) Project.

\begin{abstract}
Alternaria leaf petiole and stem blight (Alternaria spp.) is an important sweetpotato (Ipomoea batatas (L.) Lam.) disease in Uganda. Severity of the disease varies with environment, with higher disease levels recorded under high moisture and humidity conditions. To breed for resistance to this disease, germplasm that is resistant must be identified through multi-locational trials. This study was conducted to evaluate selected sweetpotato genotypes for stable resistance to Alternaria blight across sites and seasons. Thirty sweetpotato genotypes from different agro-ecological zones of Uganda and the National Sweetpotato Program were evaluated for resistance to Alternaria blight using fungicide treatment and Alternaria blight pathogen inoculation at Namulonge and Kachwekano over three seasons. There were highly significant differences among the genotypes for Alternaria blight severity with higher disease levels at Kachwekano than Namulonge. Genotypes Shock, Silk Luwero and the resistant check Tanzania had the lowest Alternaria severity and were therefore the most resistant while NASPOT 1 and NASPOT 7 had the highest severity values and were the most susceptible. Improved cultivars were more susceptible than the landraces. Genotypes Tanzania and Namusoga and environment Namulonge 2015B were the most stable for Alternaria blight. Treatment with fungicide resulted in variable reductions in Alternaria blight severity among genotypes across seasons and sites with NASPOT 1 having the lowest percentage reduction of $40.8 \%$ between the Alternaria inoculated and fungicide treated plots. Kigaire recorded the highest percentage disease reduction of $63.6 \%$. Those genotypes with acceptable performance for Alternaria blight may be used as parents in breeding new genotypes with improved performance.
\end{abstract}

Keywords: Genotypes, stable resistance, Alternaria blight, landrace, environment

\section{Introduction}

Sweetpotato (Ipomoea batatas (L.) Lam.) production in Uganda is constrained by several biotic and abiotic factors. Among the biotic factors are: sweetpotato weevil (Cylas spp.) (Stathers et al., 2003), sweetpotato virus disease (SPVD) (Mwanga et al., 2002) and Alternaria leaf petiole and stem blight (Alternaria spp.) commonly referred to as Alternaria blight (Skoglund et al., 1994; Anginyah et al., 2001; Osiru et al., 2007a; Osiru et al., 2007b). Alternaria blight is the most important sweetpotato fungal disease in Uganda (Mwanga et al., 2007b; Osiru et al., 2007a; Osiru et al., 2007b) especially in areas of mid to high altitude (Turyamureba et al., 2000; Osiru et al., 2007a; Mwanga \& Ssemakula, 2011, Yada et al., 2013) and in other parts of Africa (Anginyah et al., 2001; Narayanin et al., 2010a). Both A. bataticola and A. alternata have been isolated from infected sweetpotato plants but $A$. bataticola is the more aggressive species (Anginyah et al., 2001; Osiru et al., 2007a; Osiru et al., 2007b) with a high genotype by environment by season interaction (Musabyemungu et al., 2019). Previous 
studies have indicated high yield losses due to Alternaria blight ranging from 27.3 to $54.3 \%$ in susceptible genotypes (Osiru et al., 2007b). With such high losses, it is necessary to put in place control measures that can curb the losses. Several measures have been suggested to control Alternaria blight of sweetpotato. However, given that sweetpotato is a low value crop grown mainly by resource poor farmers, the most cost-effective control method is the use of host plant resistance (HPR) (Ames et al., 1996).

In order to breed for HPR, there is a need to identify sources of resistance among the existing genotypes, which may be used as parents in an improvement program. Studies by Turyamureba et al. (2000), Osiru et al. (2007b), and Niringiye et al. (2014a) in Uganda; van Bruggen (1984) in Ethiopia; Anginyah et al. (2001) in Kenya; Lopes and Boiteux (1994) in Brazil; Kandolo et al. (2016) and Narayanin et al. (2010b) in South Africa, indicated variation in resistance to Alternaria blight within the sweetpotato germplasm. This variation in resistance is an indication that it is possible to select desirable parents from within the existing germplasm and breed for resistance to Alternaria blight. To develop new resistant genotypes, the parental genotypes with appreciably higher levels of resistance can be selected for areas with high incidence of the Alternaria blight. This necessitates that potential parents be evaluated for stability in the expression of Alternaria blight resistance and agronomic performance across environments.

In their study to determine the reaction of elite genotypes to Alternaria blight and associated yield losses, Osiru et al. (2007b) depended on natural disease infection to identify resistant genotypes. However, natural infection may not always be very reliable given that the inoculum pressure may be too low to give good differentiation between resistant and susceptible genotypes with some even escaping disease infection. They highlighted the need to inoculate some plots with Alternaria blight inoculum in order to establish adequate disease pressure and also to spray other plots with a fungicide to reduce the disease level as much as possible. This would enable calculation of the disease reduction in the fungicide treated plots relative to the inoculated ones.

Selection of superior genotypes across several environments is almost always complicated by genotype $\times$ environment interaction (GEI) (Eberhart \& Russell, 1966). The effect of GEI in plant breeding programs is to reduce the correlation between the phenotype and the genotype potentially resulting in invalid or biased conclusions about genetic variance if the GEI effects are not taken into account (Collins et al., 1987). Many important traits in sweetpotato are sensitive to environmental change as evidenced in several studies (Naskar \& Singh, 1992; Manrique \& Hermann, 2000; Grüneberg et al., 2005; Osiru et al., 2009; Niringiye et al., 2014b). It is therefore important to quantify the GEI and determine the stability of the different genotypes through the application of appropriate statistical analyses to multi-locational and multi-seasonal trials (Thomason \& Philips, 2006). The additive main effects and multiplicative interaction (AMMI) (Gauch, 2006) is the model of choice when main effects and interactions are both important (Zobel et al., 1988) and can be used to identify both superior and stable genotypes (Crossa, 1990).

This study was conducted to evaluate selected sweetpotato genotypes for resistance and stability to Alternaria blight across two sites and three seasons.

\section{Method}

\subsection{Genotypes}

A total of 30 genotypes were selected comprising of 13 farmer landraces commonly grown in different regions of Uganda, 5 farmers' cultivars that were evaluated by the National Sweetpotato Program and released by the Variety Release Committee (VRC), 8 cultivars bred by the National Sweetpotato Program and released by the VRC, and 4 promising genotypes (pre-release) from the National Sweetpotato Program (Table 1). 
Table 1. Sweetpotato genotypes evaluated at Namulonge and Kachwekano (2015-2016)

\begin{tabular}{|c|c|c|c|c|c|c|c|}
\hline \multirow{2}{*}{ Genotype } & \multirow{2}{*}{ District } & \multirow{2}{*}{ Status } & \multirow{2}{*}{$\begin{array}{l}\text { Maturity } \\
\text { (days) }\end{array}$} & \multirow{2}{*}{$\begin{array}{l}\text { Av. Yield } \\
\left(\mathrm{t} \mathrm{ha}^{-1}\right)\end{array}$} & \multirow{2}{*}{$\begin{array}{l}\text { Root dry matter content } \\
(\%)\end{array}$} & \multicolumn{2}{|c|}{ Resistance to SPVD and weevils } \\
\hline & & & & & & SPVD & Weevils \\
\hline Semanda & Mpigi & Landrace & 120 & 20.8 & 31.3 & MR & $\mathrm{S}$ \\
\hline Silk Luwero & Luwero & Land race & 120 & 7.7 & 34.0 & $\mathrm{~S}$ & \\
\hline Kidodo & & Landrace & $120-150$ & 17.5 & 30.3 & MR & \\
\hline Dimbuka & Rakai & Landrace & $120-150$ & 19.7 & 31.5 & $\mathrm{~S}$ & S \\
\hline Araka Red & Soroti & Landrace & $120-150$ & 8.8 & 32.1 & MR & S \\
\hline MBL 170 & Mpigi & Landrace & $120-150$ & 10.6 & 33.0 & - & - \\
\hline Shock & Mbale & Landrace & $120-150$ & 15.0 & 32.6 & MR & - \\
\hline Magabali & Kabale & Landrace & 165 & 19.1 & 33.3 & MR & MR \\
\hline Budde & Masaka & Landrace & $120-150$ & 10.1 & 31.4 & MR & - \\
\hline Kigaire & Soroti & Landrace & 120 & 9.2 & 32.0 & MR & MR \\
\hline MBR 536 & Mbarara & Landrace & $120-150$ & 8.8 & 32.0 & - & - \\
\hline Namusoga & Kamuli & Landrace & 120 & 15.0 & 34 & & MR \\
\hline Otada & Lira & Landrace & $120-150$ & 21.6 & 30.7 & - & - \\
\hline Tanzania & - & Landrace- $\mathrm{R}$ & 120 & 22.9 & 32 & MR & S \\
\hline Bwanjule & - & Landrace- $\mathrm{R}$ & $120-150$ & 21.4 & 30 & MR & S \\
\hline New Kawogo & - & Landrace- $R$ & $130-150$ & 23.3 & 33 & HR & MR \\
\hline NASPOT 1 & - & Released-C & $120-150$ & 29.0 & 33 & MR & S \\
\hline NASPOT 2 & - & Released-C & $120-150$ & 21.0 & 29 & $\mathrm{R}$ & S \\
\hline NASPOT 3 & - & Released-C & $130-150$ & 25.0 & 35 & $\mathrm{R}$ & MR \\
\hline NASPOT 4 & - & Released-C & $130-150$ & 21.0 & 33 & $\mathrm{R}$ & MR \\
\hline NASPOT 7 & - & Released-C & 115 & 20.4 & 31.7 & MR & S \\
\hline NASPOT 8 & - & Released-C & 120 & 17.8 & 32.0 & MR & S \\
\hline NASPOT $10 \mathrm{O}$ & - & Released-C & 110 & 16.5 & 30.5 & MR & S \\
\hline NASPOT 11 & - & Released-C & 115 & 33.5 & 26.5 & MR & S \\
\hline Ejumula & - & Released-R & $120-150$ & 18.8 & 30.1 & S & S \\
\hline SPK004 & - & Released-R & $120-150$ & 14.9 & 33.2 & MR & S \\
\hline NKA259L & - & Pre-release & $120-150$ & 31.8 & 33.6 & MR & MR \\
\hline BND145L & - & Pre-release & $120-150$ & 28.1 & 32.5 & MR & MR \\
\hline NKA318L & - & Pre-release & $120-150$ & 26.3 & 32.3 & MR & $\mathrm{R}$ \\
\hline NKA103M & - & Pre-release & $120-150$ & 33.8 & 32.8 & MR & MR \\
\hline
\end{tabular}

Note. Landrace- $\mathrm{R}=$ Released landrace; Released-C $=$ Released cultivar; $\mathrm{S}=$ Susceptible; $\mathrm{R}=$ Resistant; $\mathrm{MR}=$ moderately resistant; $\mathrm{SPVD}=$ Sweetpotato virus disease.

Sources: Mwanga et al. (2001a); Mwanga et al. (2003b); Mwanga et al. (2007a); Mwanga et al. (2011); Mwanga et al. (2009), Mwanga et al. (2011); Yada et al. (2010).

\subsection{Trial Site Description}

The trials were established at two sites. The first site was at the National Crops Resources Research Institute (NaCRRI) at Namulonge (27 km from Kampala) at $0^{\circ} 32^{\prime} \mathrm{N}, 32^{\circ} 35^{\prime} \mathrm{E}$; 1150 metres above sea level (masl) in Wakiso district, central Uganda. This location has a bimodal rainfall pattern with annual rainfall range of $1000-1200 \mathrm{~mm}$ and annual mean temperature of $21^{\circ} \mathrm{C}$. The second site was at Kachwekano Zonal Agricultural Research and Development Institute (KAZARDI) (400 km from Kampala) at $01^{\circ} 16^{\prime} \mathrm{S}, 29^{\circ} 57^{\prime} \mathrm{E}$; 2200 masl in Kabale district in south-western Uganda. It has a bimodal rainfall pattern with annual rainfall ranging between $1200-1500 \mathrm{~mm}$ and annual mean temperature of $18{ }^{\circ} \mathrm{C}$. These sites are located in two of the main sweetpotato production regions of the country and Alternaria blight disease is common at both sites (Osiru et al., 2007a). Kachwekano is a "hotspot" for the Alternaria blight, and Namulonge is a medium disease pressure zone for Alternaria blight but a "hotspot" for SPVD (Mwanga et al., 2007b).

\subsection{Trial Establishment and Field Layout}

The trials were laid out in a $5 \times 6$ row-column design replicated three times. Seventeen vine-tip cuttings, each $0.30 \mathrm{~m}$ in length, were planted $0.30 \mathrm{~m}$ apart in each of the four, $5 \mathrm{~m}$ long ridged rows spaced $1 \mathrm{~m}$ apart per plot. The two left rows of the plot were sprayed once with a spore suspension of Alternaria inoculum (concentration

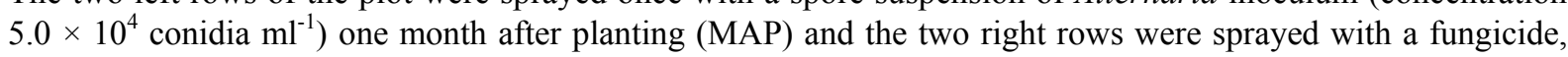


Indofil M-45 (Mancozeb, 80\%) according to the manufacturer's instructions at two-week intervals. The inoculum was prepared according to Van Bruggen (1984). No fertilizers or irrigation was applied and the plots were weeded manually. This trial was repeated at the same sites using the same layout and genotypes for three seasons. The seasons were: first planting season of 2015 (2015A) from March to July; second planting season of 2015 (2015B) from September 2015 to January 2016; and first planting season of 2016 (2016A) from March to July. The crop at Namulonge was harvested at 5 MAP. However, due to the lower temperatures at Kachwekano, the crop was harvested at 7 MAP. Cultivars Tanzania and NASPOT 1 were included as resistant and susceptible checks, respectively (Osiru et al., 2007b).

\subsection{Data Collection}

\subsubsection{Alternaria Leaf Petiole and Stem Blight Rating}

Alternaria blight disease severity was scored starting at three weeks after inoculation and continued at one-month intervals such that four data sets were collected. The disease severity rating scoring was done by inspection of individual plants for symptoms and rating was done using a subjective visual scale of 0 to 5 modified after van Bruggen (1984), where, $0=$ no disease; $1=<1 \% ; 2=1$ to $10 \% ; 3=11$ to $25 \% ; 4=26$ to $50 \%$; and $5=>50 \%$ foliar infection. The disease severity scores were expressed on a plot mean basis. The rows sprayed with Alternaria inoculum and those sprayed with the fungicide were scored separately. Disease severity data for each cropping season and site was used to calculate the Area Under Disease Progress Curve (AUDPC) according to Shaner and Finney (1977).

$$
\mathrm{AUDPC}=\sum_{\mathrm{i}=1}^{\mathrm{n}}\left[\left(\mathrm{X}_{\mathrm{i}+1}+\mathrm{X}_{\mathrm{i}}\right) / 2\right]\left[\mathrm{t}_{\mathrm{i}+1}-\mathrm{t}_{\mathrm{i}}\right]
$$

Where, $X_{i}=$ infected leaf area (\%) at the $i^{\text {th }}$ observation; $t_{i}=$ time (days) at the $i^{\text {th }}$ observation; $n=$ total number of observations.

The percentage disease reduction was calculated as:

\subsection{Data Analysis}

$$
\text { Disease reduction }(\%)=\frac{\text { Mean AUDPC (Fungicide spray) }- \text { Mean AUDPC (Alternaria spray) }}{\text { Mean AUDPC (Alternaria spray) }} \times 100
$$

The analysis of variance (ANOVA) was conducted using the generalised linear model of SAS version 9.3 (SAS Institute, 2010). Data were first analysed for each site separately and then homogeneity of the error variances for the environments was tested using Hartley's $\mathrm{F}_{\max }$ test (Hartley, 1950); the differences were not significant ( $\mathrm{P} \leq$ 0.05). The combined ANOVA was generated using the generalised linear model of SAS version 9.3 (SAS Institute, 2010).

Each combination of site and season was considered to be a different environment, thus two sites over three seasons equal to six environments. To determine the effects of GEI, the data were subjected to AMMI analysis by GENSTAT $14^{\text {th }}$ Edition (Payne et al., 2011) using the following model:

$$
\mathrm{Y}_{\mathrm{ge}}=\mu+\alpha_{\mathrm{g}}+\beta_{\mathrm{e}}+\sum_{\mathrm{n}=1}^{\mathrm{N}} \lambda_{\mathrm{n}} \gamma_{\mathrm{gn}} \eta_{\mathrm{en}}+\theta_{\mathrm{ge}}+\xi_{\mathrm{ij}}
$$

Where, $\mathrm{Y}_{\mathrm{ge}}$ is the yield (or other traits) of genotype $\mathrm{g}$ in environment, $\mathrm{e} ; \mu$ is the grand mean; $\alpha_{\mathrm{g}}$ is the genotype mean deviation; $\beta_{\mathrm{e}}$ is the environment mean deviation; $\mathrm{N}$ is the number of interaction principal component analysis (IPCA) axes retained in the model; $\lambda_{\mathrm{n}}$ is the eigen value of the interaction principal component analysis axis (IPCA) $n ; \gamma_{\mathrm{gn}}$ and $\eta_{\mathrm{en}}$ are genotype and environment IPCA scores for the $\mathrm{n}^{\text {th }}$ IPCA axis; $\theta_{\mathrm{ge}}$ is the residual of the GEI unaccounted for by the IPCA axes; and $\xi_{\mathrm{ij}}$ is the experimental error.

For this study stability index, AMMI Stability Value (ASV) (Purchase et al., 2000) was used to identify stable genotypes. The interaction patterns of the genotypes and the environments were graphically represented in a biplot of the respective IPCA1 scores (y-axis) versus the genotype and environmental means (x-axis) or IPCA2 for the Alternaria blight AUDPC. In the biplot, displacement in the horizontal plane reflects differences in the mean performance, while displacement in the vertical plane reflects differences in interaction effects (Zobel et al., 1988).

The ASV is calculated using Pythagoras' theorem as the distance (hypotenuse) from the coordinate point to the origin in a two-dimensional biplot of IPCA1 scores versus IPCA2 scores. Since the IPCA1 axis contributes more to the GEI sum of squares (SS) than the IPCA2 axis, the IPCA1 score is weighted in the calculation of the ASV by the ratio of the IPCA1 SS to the IPCA2 SS as follows:

$$
\mathrm{ASV}_{\mathrm{i}}=\sqrt{\left[\frac{\text { IPCA1 SS }}{\mathrm{IPCA} 2 \mathrm{SS}}(\mathrm{IPCA} 1 \text { score })\right]^{2}+(\mathrm{IPCA} 2 \text { score })^{2}}
$$


The larger the IPCA score for a genotype either negative or positive, the greater the interaction of a genotype with certain environments. Consequently, the genotype with the lowest ASV is the most stable and that with the highest ASV the least stable.

\section{Results}

\subsection{Analysis of Variance for Alternaria AUDPC at Namulonge and Kachwekano During the Three Seasons}

The genotypes, the spray treatments and site effects were highly significantly $(\mathrm{P}<0.001)$ different for the AUDPC (Table 2). Similarly, seasonal effects were also highly significant $(P<0.001)$ for AUDPC. Genotype $\times$ spray treatment interaction was not significant $(\mathrm{P}>0.05)$ for all traits. The genotype $\times$ site interaction was highly significant $(P<0.001)$. Similarly, genotype $\times$ season interaction was significant $(P<0.01)$. Genotype $\times$ site $\times$ treatment interaction was not significant $(\mathrm{P}>0.05)$. Genotype $\times$ site $\times$ season interaction was highly significant $(\mathrm{P}<0.001)$. Genotype $\times$ season $\times$ spray treatment and spray treatment $\times$ site $\times$ season interactions were not significant $(\mathrm{P}>0.05)$. Furthermore, genotype $\times$ spray treatment $\times$ site $\times$ season interaction was not significant $(P>0.05)$ for AUDPC. Significant differences between means are only discussed for the significant three way interaction (genotype $\times$ site $\times$ season), two way interactions (genotype $\times$ site, site $\times$ season, genotype $\times$ season) and main effects.

Table 2. Analysis of variance mean squares for Alternaria AUDPC at Namulonge and Kachwekano during seasons 2015A, 2015B and 2016A

\begin{tabular}{|c|c|c|}
\hline Source & $\mathrm{DF}$ & AUDPC \\
\hline Site (Rep) & 4 & $1464.57 * *$ \\
\hline Genotype & 29 & $5093.92 * * *$ \\
\hline Spray treatment & 1 & $82311.49 * * *$ \\
\hline Site & 1 & $22002.21 * * *$ \\
\hline Season & 2 & $18104.11 * * *$ \\
\hline Genotype $\times$ Spray treatment & 29 & 387.06 \\
\hline Genotype $\times$ Site & 29 & $1336.66^{* * *}$ \\
\hline Genotype $\times$ Season & 58 & $677.19 * *$ \\
\hline Site $\times$ Spray treatment & 1 & 229.25 \\
\hline Site $\times$ Season & 2 & $9126.89 * * *$ \\
\hline Genotype $\times$ Spray treatment $\times$ Site & 29 & 249.92 \\
\hline Genotype $\times$ Site $\times$ Season & 58 & $949.85 * * *$ \\
\hline Genotype $\times$ Season $\times$ Spray treatment & 58 & 309.60 \\
\hline Spray treatment $\times$ Site $\times$ Season & 2 & 319.90 \\
\hline Genotype $\times$ Spray treatment $\times$ Site $\times$ Season & 58 & 256.33 \\
\hline $\mathbf{R}^{\overline{2}}$ & & 0.62 \\
\hline CV\% & & 22.90 \\
\hline
\end{tabular}

Note. $* * *=$ significant at $\mathrm{P} \leq 0.001 ; * *=$ significant at $\mathrm{P} \leq 0.01 ; *=$ significant at $\mathrm{P} \leq 0.05 ; \mathrm{A} U D P C=$ area under disease progress curve for Alternaria blight severity; Spray treatment $=$ Alternaria inoculum or fungicide treatment; 2015A = first season of 2015 (March to July 2015); 2015B = second season of 2015 (September 2015 to January 2016); 2016A = first season of 2016 (March to July 2016).

\subsection{Variation in AUDPC in Response to Site, Season, Genotype and Spray Treatment}

The effects of genotype $\times$ site were highly significant $(\mathrm{P}<0.001)$ for most traits. As the four way interaction of genotype $\times$ spray treatment $\times$ site $\times$ season was not significant $(P>0.05)$ for AUDPC (Table 2), the trends rather than significant differences between means thereof are discussed for AUDPC. The AUDPC values for the genotypes were higher at Kachwekano than at Namulonge for both spray treatments and in all seasons (Table 3). At both sites, the highest disease severity for the genotypes was recorded in season 2016A. Across seasons and sites, Shock had lower AUDPC values of 95.3 and 43.0 with the Alternaria inoculation and fungicide treatments, respectively than the resistant check, Tanzania. NASPOT 11 was the third most resistant genotype with a mean AUDPC value of 104.6 when inoculated but with higher AUDPC values at Namulonge than at Kachwekano. NASPOT 1, the susceptible check, had the highest mean AUDPC values of 162.3 and 96.1 with inoculation and fungicide treatment, respectively. In addition to NASPOT 1, New Kawogo (145.4), Dimbuka (137.8) and 
NASPOT 7 (136.6) were the most susceptible when inoculated with the Alternaria pathogens. Correspondingly, they had higher AUDPC values when sprayed with fungicide.

With respect to Alternaria blight severity, treatment with fungicide resulted in variable reductions in severity among genotypes across seasons and sites (Table 3). NASPOT 1 recorded the lowest percentage reduction in disease severity of $40.8 \%$ between the Alternaria inoculated and fungicide treated plants. Kigaire recorded the highest percentage disease reduction of $63.6 \%$.

Table 3. Genotype means for Alternaria blight AUDPC values with Alternaria inoculum and fungicide spray treatments at Namulonge and Kachwekano during the 2015A, 2015B and 2016A seasons

\begin{tabular}{|c|c|c|c|c|c|c|c|c|c|c|c|c|c|c|c|c|c|}
\hline \multirow{3}{*}{ Genotype } & \multicolumn{3}{|c|}{ Namulonge } & \multicolumn{3}{|c|}{ Kachwekano } & \multirow{3}{*}{ Mean } & \multirow{3}{*}{ Rank } & \multicolumn{3}{|c|}{ Namulonge } & \multicolumn{3}{|c|}{ Kachwekano } & \multirow{3}{*}{ Mean } & \multirow{3}{*}{ Rank } & \multirow{3}{*}{$\% D R$} \\
\hline & 2015A & 2015B & 2016A & 2015A & 2015B & 2016A & & & 2015A & 2015B & 2016A & 2015A & 2015B & 2016A & & & \\
\hline & ASP & ASP & ASP & ASP & ASP & ASP & & & FSP & FSP & FSP & FSP & FSP & FSP & & & \\
\hline Araka Red & 135.5 & 114.5 & 139.0 & 128.5 & 142.5 & 125.0 & 130.8 & 24 & 71.0 & 60.5 & 57.0 & 57.0 & 67.5 & 88.5 & 66.9 & 22 & -48.9 \\
\hline BND145L & 121.5 & 97.0 & 135.5 & 107.5 & 128.5 & 128.5 & 119.8 & 18 & 57.0 & 29.0 & 53.5 & 46.5 & 78.0 & 64.0 & 54.7 & 10 & -54.3 \\
\hline Bwanjule & 114.5 & 90.0 & 121.5 & 97.0 & 107.5 & 86.5 & 102.8 & 3 & 53.5 & 32.5 & 22.0 & 36.0 & 46.5 & 60.5 & 41.8 & 2 & -59.3 \\
\hline Dimbuka & 146.0 & 125.0 & 149.5 & 128.5 & 125.0 & 152.5 & 137.8 & 28 & 78.0 & 71.0 & 92.0 & 60.5 & 67.5 & 85.0 & 75.7 & 27 & -45.1 \\
\hline Ejumula & 125.0 & 107.5 & 121.5 & 114.5 & 107.5 & 126.5 & 117.1 & 15 & 60.5 & 50.0 & 57.0 & 57.0 & 50.0 & 67.5 & $\mathbf{5 7 . 0}$ & 11 & -51.3 \\
\hline Kigaire & 100.5 & 104.0 & 114.5 & 97.0 & 111.0 & 104.0 & 105.2 & 5 & 46.5 & 36.0 & 32.3 & 22.0 & 32.5 & 60.5 & 38.3 & 1 & -63.6 \\
\hline Magabali & 111.0 & 97.0 & 132.0 & 104.0 & 118.0 & 132.0 & 115.7 & 11 & 57.0 & 46.5 & 71.0 & 60.5 & 64.0 & 74.5 & 62.3 & 18 & -46.2 \\
\hline Malagalya & 121.5 & 128.5 & 125.0 & 100.5 & 97.0 & 111.0 & 113.9 & 10 & 67.5 & 71.0 & 50.0 & 67.5 & 43.0 & 53.5 & 58.8 & 13 & -48.4 \\
\hline MBL 170 & 97.0 & 93.5 & 121.5 & 118.0 & 132.0 & 146.0 & 118.0 & 16 & 29.0 & 36.0 & 92.0 & 57.0 & 64.0 & 71.0 & 58.2 & 12 & -50.7 \\
\hline MBR 536 & 114.5 & 79.5 & 111.0 & 107.5 & 118.0 & 114.5 & 107.5 & 6 & 67.5 & 29.0 & 53.5 & 64.0 & 50.0 & 50.0 & 52.3 & 8 & -51.3 \\
\hline Namusoga & 100.5 & 93.5 & 132.0 & 111.0 & 111.0 & 111.0 & 109.8 & 8 & 46.5 & 43.0 & 53.5 & 53.5 & 60.5 & 67.5 & 54.1 & 9 & -50.7 \\
\hline New Kawogo & 121.5 & 125.0 & 135.5 & 167.0 & 149.5 & 174.0 & 145.4 & 30 & 64.0 & 64.0 & 113.0 & 102.5 & 78.0 & 78.0 & 83.3 & 30 & -42.7 \\
\hline NKA103M & 100.5 & 90.0 & 118.0 & 139.0 & 107.5 & 140.5 & 115.9 & 20 & 36.0 & 32.5 & 81.5 & 78.0 & 57.0 & 71.0 & 59.3 & 21 & -48.8 \\
\hline NKA259L & 97.0 & 100.5 & 128.5 & 139.0 & 114.5 & 139.0 & 119.8 & 4 & 50.0 & 39.5 & 67.5 & 78.0 & 57.0 & 64.0 & 59.3 & 5 & -50.5 \\
\hline NKA318L & 93.5 & 97.0 & 135.5 & 128.5 & 146.0 & 146.0 & 124.4 & 22 & 32.5 & 43.0 & 95.5 & 60.5 & 88.5 & 67.5 & 64.6 & 23 & -48.1 \\
\hline NASPOT 1 & 135.5 & 149.5 & 177.5 & 146.0 & 170.5 & 194.5 & 162.3 & 8 & 74.5 & 85.0 & 127.0 & 78.0 & 106.0 & 106.0 & 96.1 & 7 & -40.8 \\
\hline NASPOT $10 \mathrm{O}$ & 132.0 & 107.5 & 132.0 & 121.5 & 132.0 & 121.5 & 124.4 & 26 & 64.0 & 43.0 & 60.5 & 67.5 & 74.5 & 85.0 & 65.8 & 27 & -47.1 \\
\hline NASPOT 11 & 107.5 & 100.5 & 132.0 & 93.5 & 86.5 & 107.5 & 104.6 & 27 & 50.0 & 39.5 & 36.0 & 39.5 & 39.5 & 78.0 & 47.1 & 26 & -55.0 \\
\hline NASPOT 2 & 93.5 & 104.0 & 128.5 & 139.0 & 139.0 & 160.0 & 127.3 & 14 & 36.0 & 43.0 & 99.0 & 74.5 & 81.5 & 74.5 & 68.1 & 19 & -46.5 \\
\hline NASPOT 3 & 135.5 & 90.0 & 121.5 & 93.5 & 111.0 & 107.5 & 109.8 & 29 & 64.0 & 39.5 & 50.0 & 29.0 & 60.5 & 67.5 & 51.8 & 29 & -52.8 \\
\hline NASPOT 4 & 121.5 & 125.0 & 142.5 & 132.0 & 132.0 & 156.5 & 134.9 & 12 & 64.0 & 67.5 & 95.5 & 81.5 & 71.0 & 74.5 & 75.7 & 15 & -43.9 \\
\hline NASPOT 7 & 156.5 & 125.0 & 146.0 & 121.5 & 121.5 & 148.8 & 136.6 & 18 & 88.5 & 60.5 & 74.5 & 67.5 & 64.0 & 88.5 & 73.9 & 15 & -45.9 \\
\hline NASPOT 8 & 100.5 & 111.0 & 121.5 & 121.5 & 118.0 & 128.2 & 116.8 & 20 & 78.0 & 53.5 & 60.5 & 67.5 & 64.0 & 64.0 & 64.6 & 19 & -44.7 \\
\hline OTADA & 114.5 & 86.5 & 118.0 & 123.5 & 121.5 & 135.5 & 116.6 & 13 & 46.5 & 32.5 & 81.5 & 60.5 & 74.5 & 67.5 & 60.5 & 17 & -48.1 \\
\hline Semanda & 97.0 & 97.0 & 121.5 & 139.0 & 118.0 & 142.5 & 119.2 & 17 & 39.5 & 29.0 & 81.5 & 78.0 & 67.5 & 57.0 & 58.8 & 13 & -50.7 \\
\hline Shock & 58.5 & 76.0 & 97.0 & 104.0 & 125.0 & 111.0 & 95.3 & 1 & 25.5 & 32.5 & 50.0 & 46.5 & 60.5 & 43.0 & 43.0 & 3 & -54.9 \\
\hline Sowola 6 & 128.5 & 118.0 & 128.5 & 128.5 & 149.5 & 133.5 & 131.1 & 25 & 67.5 & 57.0 & 81.5 & 64.0 & 88.5 & 71.0 & 71.6 & 25 & -45.4 \\
\hline SPK004 & 132.0 & 114.5 & 128.5 & 132.0 & 111.0 & 149.5 & 127.9 & 23 & 71.0 & 60.5 & 88.5 & 74.5 & 57.0 & 67.5 & 69.8 & 24 & -45.4 \\
\hline Tanzania & 97.0 & 97.0 & 107.5 & 111.0 & 90.0 & 86.5 & 98.2 & 2 & 32.5 & 36.0 & 25.5 & 57.0 & 64.0 & 50.0 & 44.2 & 4 & -55.0 \\
\hline Silk Luwero & 76.0 & 104.0 & 121.5 & 118.0 & 111.0 & 121.5 & 108.7 & 7 & 29.0 & 32.5 & 52.7 & 67.5 & 53.5 & 64.0 & 49.9 & 6 & -54.1 \\
\hline Mean & 112.9 & 104.9 & 128.2 & 120.4 & 121.7 & 131.4 & & & 54.9 & 46.5 & 68.5 & 61.8 & 64.4 & 69.4 & & & \\
\hline SE & 11.3 & 9.1 & 8.4 & 18.7 & 14.5 & 15.0 & & & 8.0 & 5.1 & 5.1 & 9.9 & 21.8 & 10.5 & & & \\
\hline $\operatorname{LSD}_{(0.05)}$ & 32.1 & 25.8 & 23.7 & 51.8 & 41.1 & 42.5 & & & 22.7 & 14.4 & 14.6 & 27.9 & 61.7 & 29.7 & & & \\
\hline
\end{tabular}

Note. Seasons 2015A, 2015B, 2016A = the first season of 2015 (March to July 2015), second season of 2015 (September 2015 to January 2016), and first season of 2016 (March to July 2016), respectively; ASP = inoculated with Alternaria inoculum; FSP $=$ fungicide sprayed; $\% \mathrm{DR}=$ percentage disease reduction by the fungicide and is the difference between mean AUDPC for fungicide spray and mean AUDPC for Alternaria inoculum spray treatment expressed as a percentage of mean AUDPC for Alternaria inoculum spray treatment.

\subsection{Stability of Genotypes for Alternaria Blight Severity Across Six Environments}

The AMMI analysis was conducted for AUDPC which indicated Alternaria blight severity for 30 sweetpotato genotypes evaluated in twelve environments. 


\subsubsection{Stability for Alternaria Blight Reaction}

The genotypes, environments and GEI effects were highly significant for AUDPC $(\mathrm{P}<0.001)$ (Table 4). The genotypes, environments and GEI accounted for 18.8, 8.1 and $16.8 \%$, respectively of the total SS for AUDPC (expressed as a mean of the Alternaria inoculation and fungicide spray treatments for each genotype). Only IPCA1 and IPCA2 were significant $(\mathrm{P}<0.0001)$ and accounted for 47.3 and $30.2 \%$, respectively of the GEI SS.

Table 4. AMMI analysis for Alternaria blight severity for 30 sweetpotato genotypes evaluated in twelve environments

\begin{tabular}{llllll}
\hline Source & df & SS & MS & \%Total SS & \%GEI SS \\
\hline Total & 1079 & 934661 & 866 & & \\
Treatments & 359 & 574018 & $1599 * * *$ & 61.4 & \\
Genotypes (G) & 29 & 187014 & $6449 * * *$ & 20.0 & \\
Environments (E) & 11 & 171846 & $15622^{* *}$ & 18.4 & 23.0 \\
Interactions (GxE) & 319 & 215158 & $674 * * *$ & & 33.7 \\
IPCA1 & 39 & 81833 & $2098 * * *$ & & 28.3 \\
IPCA2 & 37 & 72473 & $1959 * * *$ & & \\
Residuals & 243 & 60852 & 250 & & \\
Error & 695 & 337565 & 486 & & \\
\hline
\end{tabular}

Note. $* * *$ = significant at $\mathrm{P}<0.0001 ; \mathrm{df}=$ degrees of freedom; $\mathrm{SS}=$ sum of squares; $\mathrm{MS}=$ mean square; \% Total $\mathrm{SS}=$ percentage of total sum of squares; \%GEI SS = percentage of genotype $\times$ environment interaction sum of squares; IPCA = interaction principal component axis.

The rank order of the performance of the genotypes changed across the six environments (Table 5). However, some genotypes were consistently ranked as resistant and others were consistently ranked as susceptible. A genotype with the highest AUDPC mean AMMI estimate was considered to be the most susceptible and was ranked last $\left(30^{\text {th }}\right)$ while the genotype with the lowest AUDPC was the most resistant and was ranked first. NASPOT 1 was the most susceptible genotype in four of the six environments and ranked second most susceptible in the other two environments. New Kawogo and MBR 536 were the most susceptible genotypes at Namulonge 2015A and Namulonge 2015B, respectively. NASPOT 7 was the second most susceptible genotype in four of the environments. Shock was the most resistant genotype in four of the environments and NASPOT 3 the most resistant in the other two environments. Kigaire exhibited consistency in resistance to the disease and was second most resistant in two environments and third most resistant in three of the environments. 
Table 5. Mean AMMI performance estimates and ranking of the genotypes for Alternaria blight AUDPC in six environments of Uganda from 2015 to 2016

\begin{tabular}{|c|c|c|c|c|c|c|c|c|c|c|c|c|}
\hline \multirow{2}{*}{ Genotype } & \multicolumn{2}{|c|}{ NAM1 } & \multicolumn{2}{|c|}{ NAM2 } & \multicolumn{2}{|c|}{ NAM3 } & \multicolumn{2}{|c|}{ KAC1 } & \multicolumn{2}{|c|}{ KAC2 } & \multicolumn{2}{|c|}{ KAC3 } \\
\hline & Mean & Rank & Mean & Rank & Mean & Rank & Mean & Rank & Mean & Rank & Mean & Rank \\
\hline Araka Red & 92.9 & 17 & 104.9 & 24 & 92.3 & 14 & 105.6 & 27 & 87.9 & 24 & 109.6 & 24 \\
\hline BND145L & 75.1 & 5 & 104.4 & 22 & 91.3 & 12 & 87.7 & 19 & 68.4 & 10 & 96.4 & 15 \\
\hline Bwanjule & 65.7 & 3 & 77.5 & 5 & 56.0 & 1 & 86.0 & 17 & 64.6 & 7 & 84.2 & 4 \\
\hline Dimbuka & 94.3 & 18 & 96.4 & 18 & 120.7 & 25 & 109.3 & 28 & 97.6 & 28 & 122.1 & 29 \\
\hline Ejumula & 85.1 & 10 & 79.2 & 6 & 90.0 & 10 & 89.3 & 20 & 79.5 & 19 & 99.2 & 19 \\
\hline Kigaire & 62.5 & 2 & 69.9 & 3 & 70.1 & 3 & 79.8 & 12 & 63.1 & 4 & 85.1 & 5 \\
\hline Magabali & 81.7 & 7 & 91.4 & 15 & 102.4 & 16 & 84.8 & 13 & 74.0 & 17 & 99.6 & 20 \\
\hline Malagalya & 88.3 & 14 & 67.4 & 2 & 78.7 & 6 & 96.2 & 24 & 86.7 & 23 & 100.7 & 21 \\
\hline Mbale 170 & 87.9 & 13 & 97.7 & 19 & 120.1 & 24 & 65.2 & 5 & 64.3 & 5 & 93.3 & 11 \\
\hline MBR536 & 84.8 & 9 & 161.6 & 30 & 81.0 & 7 & 85.2 & 14 & 54.8 & 2 & 89.1 & 6 \\
\hline Namusoga & 82.7 & 8 & 85.5 & 10 & 85.3 & 9 & 78.8 & 11 & 69.1 & 11 & 90.5 & 7 \\
\hline New Kawogo & 133.5 & 30 & 114.6 & 26 & 140.1 & 29 & 85.9 & 15 & 95.8 & 27 & 116.1 & 30 \\
\hline NKA103M & 104.7 & 24 & 84.6 & 8 & 110.6 & 21 & 63.4 & 4 & 71.5 & 14 & 91.1 & 22 \\
\hline NKA259L & 106.4 & 26 & 87.0 & 12 & 103.2 & 17 & 71.2 & 9 & 75.8 & 18 & 93.6 & 10 \\
\hline NKA318L & 96.5 & 21 & 116.0 & 27 & 123.1 & 26 & 68.9 & 7 & 66.2 & 8 & 96.4 & 18 \\
\hline NASPOT 1 & 116.4 & 29 & 135.5 & 29 & 163.3 & 30 & 113.9 & 29 & 106.7 & 30 & 139.2 & 14 \\
\hline NASPOT $10 \mathrm{O}$ & 92.4 & 16 & 104.6 & 23 & 91.6 & 13 & 96.7 & 26 & 81.6 & 21 & 103.7 & 26 \\
\hline NASPOT 11 & 66.9 & 4 & 62.7 & 1 & 76.0 & 4 & 85.9 & 16 & 71.8 & 15 & 91.7 & 28 \\
\hline NASPOT 2 & 107.5 & 27 & 109.8 & 25 & 130.5 & 28 & 67.2 & 6 & 72.2 & 16 & 99.1 & 17 \\
\hline NASPOT 3 & 59.2 & 1 & 87.0 & 11 & 77.4 & 5 & 95.4 & 23 & 69.4 & 13 & 96.3 & 27 \\
\hline NASPOT 4 & 108.3 & 28 & 100.6 & 21 & 124.9 & 27 & 92.7 & 22 & 91.4 & 26 & 113.9 & 9 \\
\hline NASPOT 7 & 91.6 & 15 & 94.6 & 17 & 109.1 & 20 & 115.2 & 30 & 99.2 & 29 & 121.8 & 12 \\
\hline NASPOT 8 & 95.1 & 19 & 90.7 & 14 & 92.7 & 15 & 87.1 & 18 & 79.6 & 20 & 98.9 & 16 \\
\hline OTADA & 87.2 & 12 & 100.0 & 20 & 106.7 & 19 & 74.1 & 10 & 67.4 & 9 & 94.3 & 13 \\
\hline Semanda & 105.9 & 25 & 94.4 & 16 & 110.6 & 22 & 63.1 & 3 & 69.4 & 12 & 90.5 & 8 \\
\hline Shock & 79.0 & 6 & 90.5 & 13 & 82.1 & 8 & 48.6 & 1 & 45.0 & 1 & 69.6 & 1 \\
\hline Sowola 6 & 97.7 & 22 & 118.2 & 28 & 105.6 & 18 & 96.4 & 25 & 82.3 & 22 & 107.9 & 23 \\
\hline SPK004 & 101.2 & 23 & 85.3 & 9 & 114.5 & 23 & 92.0 & 21 & 90.2 & 25 & 110.2 & 25 \\
\hline Tanzania & 86.0 & 11 & 75.8 & 4 & 57.6 & 2 & 69.6 & 8 & 62.1 & 3 & 76.0 & 2 \\
\hline Silk Luwero & 95.2 & 20 & 80.7 & 7 & 91.1 & 11 & 61.6 & 2 & 64.3 & 6 & 82.8 & 3 \\
\hline
\end{tabular}

Note. NAM1 = Namulonge 2015A; NAM2 = Namulonge 2015B; NAM3 = Namulonge 2016A; KAC1 = Kachwekano 2015A; KAC2 = Kachwekano 2015B; KAC3 = Kachwekano 2016A; Lowest AUDPC value = Rank 1 (most resistant); Highest AUDPC value = Rank 30 (most susceptible).

In the AMMI biplot (Figure 1), susceptible genotypes were scattered in quadrants I and II while resistant genotypes were scattered in quadrants III and IV. Genotypes close to the horizontal line have low interaction with the environments and are therefore stable whereas the further away genotypes are from the horizontal line the more unstable they are. The most stable genotypes for Alternaria blight with above average mean AUDPC values and susceptibility were NASPOT 1 , Sowola 6 , NASPOT 4 and NASPOT 10 O. The most stable genotypes with below average mean values and thus resistant were Magabali, BND145L, NASPOT 8, Namusoga, Tanzania and NKA259L. Genotypes MBR 536, NASPOT 2, NKA318L, Malagalya and NASPOT 7 were the furthest away from the horizontal line and therefore the least stable for Alternaria blight severity. BND145L and NASPOT $10 \mathrm{O}$ were in opposite quadrants to each other thus their contributions to the interaction SS were in opposing directions.

Genotypes Bwanjule, NASPOT 11, NASPOT 3 were specifically adapted to environment Namulonge 2016A. Dimbuka, Araka Red, NASPOT 7 were relatively stable and adapted to environment Namulonge 2016A. NKA318L, NASPOT 2 and MBR 536 were relatively unstable with specific adaptation to Kachwekano 2015A and Kachwekano 2016A, respectively. New Kawogo was relatively unstable with above average AUDPC value with low interaction with Kachwekano 2015A and Kachwekano 2015B. None of the environments was stable for Alternaria blight; however, Namulonge 2015B, Namulonge 2016A, Kachwekano 2015A, Kachwekano 2016A were relatively more stable than Namulonge 2015A and Kachwekano 2016A. 


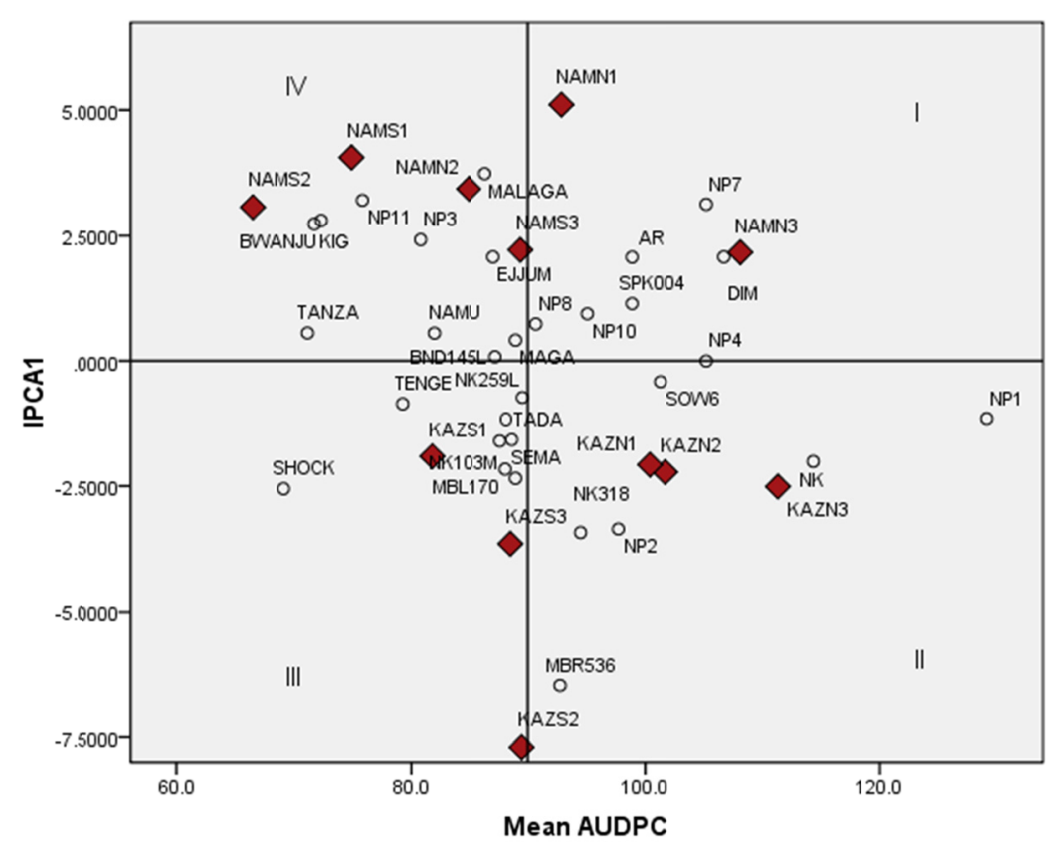

Figure 1. Biplot of mean area under disease progress curve (AUDPC) for Alternaria blight severity and the first interaction principal component axis (IPCA1) scores for 30 sweetpotato genotypes evaluated in twelve environments

Note.

\section{o Genotypes:}

TANZA $=$ Tanzania $;$ NAMU $=$ Namusoga $;$ SILKL $=$ Silk Luwero $;$ SEMA $=$ Semanda $;$ NP2 = NASPOT 2; SOW6 = Sowola 6; NK = New Kawogo; NP1 = NASPOT 1; NP4 = NASPOT 4; NP10 = NASPOT 10 O; MAGA $=$ Magabali; NP8 = NASPOT 8; KIG $=$ Kigaire; BWANJU $=$ Bwanjule; NP11 = NASPOT 11; NP3 = NASPOT 3; MALAGA = Malagalya; AR = Araka Red; NP7 = NASPOT 7; DIM = Dimbuka.

\section{- Environments:}

NAM1 = Namulonge 2015A; NAM2 = Namulonge 2015B; NAM3 = Namulonge 2016A; KAZ1 = Kachwekano 2015A; KAZ2 = Kachwekano 2015B; and KAZ3 = Kachwekano 2016A.

The biplot provides a useful diagrammatic overview of the interaction patterns of the genotypes and environments and their relative stability levels. However, for ranking purposes the AMMI model does not provide an integrated measure of stability based on scores for the first two important IPCAs. To rank the genotypes more holistically in terms of stability and performance the AMMI Stability Value (ASV) for each genotype was calculated.

The ASV ranked NASPOT 1, Namusoga and NASPOT 8 with values of $0.63,0.75$ and 0.81 as the most stable and MBR 536, NASPOT 11 and Malagalya with values of 11.09, 5.29 and 5.14 as the least stable for Alternaria blight (Table 6). 
Table 6. Mean stability rankings of 30 sweetpotato genotypes for Alternaria blight severity (expressed as AUDPC values) for ASV across twelve environments meaned for spray treatments

\begin{tabular}{|c|c|c|c|c|}
\hline Genotype & Mean AUDPC & Rank & ASV & Rank \\
\hline Araka Red & 98.9 & 24 & 1.91 & 9 \\
\hline BND145L & 87.2 & 11 & 2.10 & 10 \\
\hline Bwanjule & 72.3 & 4 & 2.86 & 16 \\
\hline Dimbuka & 106.7 & 28 & 4.07 & 22 \\
\hline Ejumula & 87.0 & 10 & 3.01 & 18 \\
\hline Kigaire & 71.7 & 3 & 3.18 & 19 \\
\hline Magabali & 89.0 & 16 & 1.25 & 7 \\
\hline Malagalya & 86.3 & 9 & 5.14 & 28 \\
\hline Mbl 170 & 88.1 & 13 & 2.39 & 12 \\
\hline MBR 536 & 92.8 & 19 & 11.09 & 30 \\
\hline Namusoga & 82.0 & 8 & 0.75 & 2 \\
\hline New Kawogo & 114.3 & 29 & 3.56 & 21 \\
\hline NKA103M & 87.6 & 12 & 2.91 & 17 \\
\hline NKA259L & 89.5 & 17 & 2.46 & 13 \\
\hline NKA318 & 94.5 & 20 & 4.63 & 25 \\
\hline NASPOT 1 & 129.2 & 30 & 0.63 & 1 \\
\hline NASPOT $10 \mathrm{O}$ & 95.1 & 21 & 0.93 & 4 \\
\hline NASPOT 11 & 75.8 & 5 & 5.29 & 29 \\
\hline NASPOT 2 & 97.7 & 22 & 4.34 & 23 \\
\hline NASPOT 3 & 80.8 & 7 & 4.37 & 24 \\
\hline NASPOT 4 & 105.3 & 27 & 1.15 & 6 \\
\hline NASPOT 7 & 105.2 & 26 & 5.11 & 27 \\
\hline NASPOT 8 & 90.7 & 18 & 0.81 & 3 \\
\hline OTADA & 88.3 & 14 & 1.76 & 8 \\
\hline Semanda & 89.0 & 15 & 3.54 & 20 \\
\hline Shock & 69.1 & 1 & 4.68 & 26 \\
\hline Sowola 6 & 101.3 & 25 & 2.16 & 11 \\
\hline SPK004 & 98.9 & 23 & 2.79 & 15 \\
\hline Tanzania & 71.2 & 2 & 1.14 & 5 \\
\hline Silk Luwero & 79.3 & 6 & 2.76 & 14 \\
\hline
\end{tabular}

Note. $\mathrm{ASV}=\mathrm{AMMI}$ stability value.

The environments were also ranked by the ASV. The ASV ranked Namulonge 2016A as the most stable environment for Alternaria blight and Kachwekano 2015B as the least stable (Table 7). 
Table 7. Mean stability ranking of the twelve test environments for Alternaria blight severity

\begin{tabular}{lllll}
\hline Environment & Environmental mean AUDPC & Rank & ASV & Rank \\
\hline KAZN1 & 100.44 & 9 & 3.70 & 6 \\
KAZN2 & 101.73 & 10 & 2.57 & 3 \\
KAZN3 & 111.38 & 12 & 5.33 & 8 \\
KAZS1 & 81.78 & 3 & 2.72 & 4 \\
KAZS2 & 89.48 & 7 & 12.30 & 12 \\
KAZS3 & 88.52 & 5 & 6.27 & 10 \\
NAMN1 & 92.87 & 8 & 6.71 & 11 \\
NAMN2 & 84.93 & 4 & 3.97 & 7 \\
NAMN3 & 108.15 & 11 & 2.45 & 1 \\
NAMS1 & 74.90 & 2 & 5.84 & 9 \\
NAMS2 & 66.50 & 6 & 3.47 & 5 \\
NAMS3 & 89.37 & 6.51 & 2 \\
\hline ASV AMMI & & 1 & 2.5 \\
\hline
\end{tabular}

Note. ASV = AMMI stability value; smallest ASV is the most stable and given rank 1; largest ASV is the most unstable and given rank 6; Kachwekano 1 = 2015A; Kachwekano 2 = 2015B; Kachwekano 3 = 2016A; Namulonge 1 =2015A; Namulonge $2=2015 B$; Namulonge $3=2016 \mathrm{~A}$.

\section{Discussion}

The severity of Alternaria blight, like many other diseases, varies with site and season. In this study, selected sweetpotato genotypes were evaluated for: resistance to Alternaria blight across seasons and sites; the stability of the genotypes for Alternaria blight resistance, and percentage disease reduction obtained from using fungicide treatment to control Alternaria blight. The resistant genotypes identified in this study can be used as sources of resistance in breeding for Alternaria blight resistance or can be recommended to farmers for cultivation in Alternaria blight affected areas.

The study indicated that the site and spray treatments main effects for AUDPC were highly significant $(\mathrm{P}<$ 0.001). Non-significance of the first order interactions for genotype $\times$ spray treatment and site $\times$ spray treatment indicated that the effects of the two spray treatments (Alternaria inoculum and fungicide spray) were consistent over genotypes and over environments. Consistent with previous reports (Osiru et al, 2007a, 2007b), Alternaria blight severity was higher at Kachwekano over the three seasons than Namulonge. This is likely to be due to differences in the environmental factors that prevailed at the two sites during the three seasons (Appendix A). In the development of Alternaria blight, it is not always the amount of rainfall that is important but also high humidity and duration of leaf wetness (dew) in the presence of the inoculum (Shrestha et al., 2005; Summuna et al., 2018). Vloutoglou and Kalogerakis (2000) reported an increase from 2 to $88 \%$ leaf area infection by $A$. solani on tomato (Solanum lycopersicum L.) when the duration of leaf wetness was increased from 4 to 24 hours and no symptoms when wetness was less than 4 hours. Similarly, Kandolo et al. (2018) reported temperature range of $20-25^{\circ} \mathrm{C}$ and wetness duration of 48 hours as the ideal conditions for the spread of Alternaria bataticola. Kachwekano had lower daily temperatures and higher relative humidity than Namulonge, consequently the residual moisture on the plants took longer to evaporate thereby facilitating the infection process.

Equally important is the age of the plants. Alternaria blight is more severe in older than in young, vigorous plants and even favourable conditions may not induce a disease outbreak in young plants but susceptibility does increase with age (Rotem, 1994; Ojiambo et al., 1999; Vloutoglou \& Kalogerakis, 2000). Since the crop was harvested at $7 \mathrm{MAP}$ at Kachwekano compared to $5 \mathrm{MAP}$ at Namulonge, the longer period in the field at Kachwekano could have increased the vulnerability of the crop. However, the importance of the age of the plants in relation to Alternaria blight severity does not exclude the fact that some genotypes like NASPOT 1 are inherently more susceptible and can succumb to the disease at an early age as long as conditions favourable for the development of the disease are present.

Some genotypes exhibited consistent performance across seasons. The resistant genotypes exhibited lower AUDPC levels across seasons and sites and, similarly, the susceptible ones had higher AUDPC values across seasons and sites. The genotypes with the lowest AUDPC were landraces and these included Shock, Tanzania and Silk Luwero. The most susceptible genotypes, NASPOT 1, NASPOT 7 and New Kawogo (a released landrace), were from the National Sweetpotato Program. These findings are in agreement with those of Osiru et al. (2007b) and Anginyah et al. (2001) who reported landraces to have lower Alternaria blight severity than improved genotypes. They attributed this to landraces having a broader genetic base than the improved 
genotypes. These resistant genotypes can be used as sources of resistance in breeding for Alternaria blight resistance.

Application of the fungicide led to a remarkable reduction in Alternaria blight severity in some genotypes; for example, Kigaire with a $63.0 \%$ reduction. In the absence of resistant genotypes, application of fungicides could help sweetpotato farmers in central Uganda where it is becoming unviable to grow their most popular cultivar NASPOT 1, which was released by the National Sweetpotato Program in 1999. It is early maturing, produces large roots, has high dry matter percentage (DM \%), good taste and good underground keeping qualities, which make it ideal for sequential harvesting. However, it is very susceptible to Alternaria blight, underscored by the $40.8 \%$ reduction in disease. In order to extend the production life of a popular cultivar such as NASPOT 1, it would therefore be necessary to use fungicides for controlling the disease with all the attendant management and economic considerations, of course.

The AMMI analysis revealed that the development of Alternaria blight is more influenced by genotype effects than by the GEI effects and to an even lesser extent by environment effects. This study has shown that some genotypes were resistant to Alternaria blight and others susceptible regardless of which of the six environments they were grown in. For example, Shock was the most resistant in most of the environments and NASPOT 1 the most susceptible. This may be an indication of stable genotypic effects whereby some genotypes are inherently more resistant even in high disease pressure areas.

The magnitude of the IPCA1 and IPCA2 from the AMMI analysis provided an indication of the stability of each genotype. The ASV ranked their stability according to a weighted combination of IPCA1 and IPCA2 scores. NASPOT 1 was ranked the most stable genotype by ASV. Tanzania and Namusoga were the best genotypes in terms of Alternaria blight resistance and stability. In the AMMI biplot, Magabali, BND145L, NASPOT 4, Sowola 6 , NASPOT 1 , NASPOT 8 , Tanzania and Namusoga were positioned close to the horizontal line and were therefore stable for the degree of resistance to Alternaria blight. However, NASPOT 1, Sowola 6, NASPOT 4, NASPOT $10 \mathrm{O}$ were stable for susceptibility to Alternaria blight and should therefore be planted in areas with low Alternaria blight pressure or protected with fungicides when planted in high pressure areas. Tanzania, Namusoga, BND145L, NASPOT 8 and Magabali were stable for Alternaria blight resistance and may be considered to be widely adapted to all of the test environments. Genotypes MBR 536, Malagalya and NASPOT 7, which were furthest from the horizontal line, have large GEI effects and are unstable for Alternaria blight expression, i.e., the severity of the disease they express changes with the environment. These genotypes may be planted in the environments to which they are well adapted but they may perform poorly when environmental conditions change and in such cases Alternaria blight control methods such as roguing of infected plants and spraying plants with fungicides may be used.

On the other hand, such genotypes may be too expensive to breed since every agro-ecological zone may require a different genotype and given the poor seed distribution system in Uganda, they may never reach the target farmers. However, in terms of agronomic considerations only, for some environments specifically adapted genotypes may be the best option.

Stability of the environments is also very important. A stable and preferably top performing environment can support stable performance of preferably the top performing test genotypes and an unstable environment can only support those that are specifically adapted to it. In this study, no environment was very stable for Alternaria blight but Namulonge 2016A and Namulonge 2015B exhibited relatively good stability with several genotypes adapted to them. Kachwekano 2015B and Namulonge 2015A were the least stable environments with no genotype specifically adapted to either of them.

\section{Conclusions}

In conclusion, the study revealed that there are differences in the reaction of different sweetpotato genotypes to Alternaria blight under Ugandan conditions with the landraces proving to be more resistant than the improved genotypes. Site and season were very important determinants of the severity of Alternaria blight on each genotype. The severity of Alternaria blight was higher at Kachwekano than at Namulonge indicative of the more favourable conditions for the development of the disease at this site. Genotypes NASPOT 8, Namusoga, NASPOT 10 O, Otada and NASPOT 1 were the most stable genotypes with the lowest AMMI ASV rank sum across AUDPC. Tanzania and Namusoga were the most stable with low Alternaria blight severity and can therefore be planted in environments with high Alternaria blight disease pressure or used as sources of resistance in breeding for resistance to Alternaria blight. Environmental stability for Alternaria blight is important in that environments that are stable for high disease pressure can be used for evaluating germplasm for Alternaria blight resistance while environments with stability for low disease pressure are suitable for seed multiplication. 


\section{Acknowledgements}

This study was partly supported by the Alliance for a Green Revolution in Africa (AGRA) and the Agricultural Technology and Agribusiness Advisory Services (ATAAS). The authors thank the National Agricultural Research Organization for providing sites for the trials at the National Crops Resources Research Institute (NaCRRI) and Kachwekano Zonal Agricultural Research and Development Institute (KAZARDI). The authors contributed equally to the study. Godfrey Sseruwu designed and implemented the study and drafted the manuscript, Mary Nanyanzi contributed to the statistical analysis and reviewed the manuscript, George Kituuka and Agnes Alajo established the field trials and coordinated the data collection, and Ian Benywanira reviewed the manuscript.

\section{References}

Ames, T., Smith, N. E. J. M., Braun, A. R., O’Sullivan, J. N., \& Skoglund, L. G. (1996). Sweetpotato: Major pests, diseases and nutritional disorders (pp. 80-81). International Potato Centre (CIP), Lima, Peru.

Anginyah, T. J., Narla, R. D., Carey, E. E., \& Njeru, R. (2001). Etiology, effect of soil pH and sweetpotato varietal reaction to Alternaria leaf petiole and stem blight in Kenya. African Crop Science Journal, 9, 287-292. https://doi.org/10.4314/ACSJ.V9I1.27650

Collins, W. W., Wilson, L. G., Arrendell, S., \& Dickey, L. F. (1987). Genotype $\times$ environment interactions in sweetpotato yield and quality factors. Journal of American Society of Horticultural Science, 112, 579-583.

Crossa, J. (1990). Statistical analysis of multilocation trials. Advances in Agronomy, 44, 55-85. https://doi.org/ 10.1016/S0065-2113(08)60818-4

Eberhart, S. A., \& Russell, W. A. (1966). Stability parameters for comparing varieties. Crop Science, 6, 36-40. https://doi.org/10.2135/cropsci1966.0011183X000600010011x

Gauch, H. G. (2006). Statistical analysis of yield trials by AMMI and GGE. Crop Science, 46, 1488-1500. https://doi.org/10.2135/cropsci2005.07-0193

Grüneberg, W. J., Manrique, K., Zhang, D., \& Hermann, M. (2005). Genotype $\times$ environment interactions for a diverse set of sweetpotato clones evaluated across varying ecogeographic conditions in Peru. Crop Science, 451, 2160-2171. https://doi.org/10.2135/cropsci2003.0533

Hartley, H. O. (1950). The use of range in analysis of variance. Biometrika, 37, 271-280. https://oi.org/10.1093/ biomet/37.3-4.271

Kandolo, S. D., Aveling, T. A. S., Van der Waals, J. E., Truter, M., \& Laurie, S. M. (2018). Effects of wetness duration, inoculum concentration and temperature on the development of Alternaria blight on transplants of sweet potato. ActaHorticulturae, 1204, 211-217. https://doi.org/10. 17660/ActaHortic.2018.1204.27

Kandolo, S. D., Thompson, A. H., Calitz, F. J., Laurie, S. M., Truter, M., Van Der Waals, J. E., \& Aveling, T. A. S. (2016). Field tolerance of selected varieties to and fungicide efficacy against Alternaria blight of sweetpotato. African Crop Science Journal, 24(3), 235-243. https://oi.org/10.4314/acsj.v24i3.2

Lopes, C. A., \& Boiteux, L. S. (1994). Leaf spot and stem blight of sweet potato caused by Alternaria bataticola: A new record to South America. Plant Disease, 78, 1107-1109. https://doi.org/10.1094/PD-78-1107

Manrique, K., \& Hermann, M. (2000). Effect of Genotype $\times$ Environment interactions on root yield and beta-carotene concentration of selected sweetpotato (Ipomoea batatas (L.) Lam.) varieties and breeding clones (Program Report 1999-2000, pp. 281-287). International Potato Centre, Lima, Peru.

Musabyemungu, A., Wasswa, P., Alajo, A., Chelagat, D. M., Otema, M. A., Musana, P., ... Yada, B. (2019). Adaptability of a U.S. purple-fleshed sweetpotato breeding population in Uganda. Australian Journal of Crop Science, 13(01), 17-25. https://doi.org/21475/ajcs.19.13.01.p1023

Mwanga, R. M. O., p'Obwoya, C. N. O., Odongo, B., \& Turyamureeba, G. M. (2001). Sweetpotatoes (Ipomoea batatas (L.) Lam.). In J. K. Mukiibi (Ed.), Agriculture in Uganda (Vol. II. p. 247). National Agricultural Research Organisation, NARO, Kampala, Uganda.

Mwanga, R. O. M., \& Ssemakula, G. (2011). Orange-fleshed sweetpotato for food, health and wealth in Uganda. International Journal of Agricultural Sustainability, 9, 42-49. https://doi.org/10.3763/ijas.2010.0546

Mwanga, R. O. M., Niringiye, C., Alajo, A., Namakula, J., Mpembe, I. Tumwgamire, S., ... Yencho. G. C. (2011). 'NASPOT 11', a sweetpotato cultivar bred by a participatory plant breeding approach in Uganda. HortScience, 46, 317-321. https://doi.org/10.21273/HORTSCI.46.2.317 
Mwanga, R. O. M., Niringiye, C., Lamega, B., Kapinga, R., Yencho, G. C., \& Odongo, B. (2007a). Breeding efforts to develop high-yielding, multiple pest-resistant sweetpotato germplasm in Uganda. In R. Kapinga, et al. (Eds.), Trends in the potato and sweetpotato sectors in sub-Saharan Africa and their contribution to the Millenium Development Goals (pp. 60-71). Arusha, Tanzania.

Mwanga, R. O. M., Odongo, B., Niringiye, C., Kapinga, R., Tumwegamire, S., Abidin, P. E., ... Zhang, D. (2007b). Sweetpotato selection releases: lessons learnt from uganda. African Crop Science Journal, 15, 11-23. https://doi.org/10.4314/acsj.v15i1.54406

Mwanga, R. O. M., Odongo, B., Turyamureeba, G., Alajo, A., Yencho, G. C., Gibson, R. W., ... Carey, E. E. (2003). Release of six sweetpotato cultivars ('NASPOT 1 to NASPOT 6') in Uganda. HortScience, 38, 475-476. https://doi.org/10.21273/HORTSCI.38.3.475

Mwanga, R. O. M., Yencho, G. C., \& Moyer, J. W. (2002). Diallel analysis of sweetpotatoes for resistance to sweetpotato virus disease. Euphytica, 128, 237-248. https://doi.org/10.1023/A:1020828421757

Narayanin, C. D., Thompson, A. H., \& Slabbert, M. M. (2010a). First report of Alternaria blight of sweet potato caused by Alternaria bataticola in South Africa. African Plant Protection, 16, 7-9.

Narayanin, C. D., Thompson, A. H., \& Slabbert, M. M. (2010b). Greenhouse screening of South African sweet potato cultivars and breeding lines for tolerance to Alternaria blight caused by Alternaria bataticola. African Plant Protection, 16(1), 10-13.

Naskar, S. K., \& Singh, D. P. (1992). Genotype $\times$ environment interaction for tuber yield in sweetpotato. Journal of Root Crops, 18, 85-88.

Niringiye, C. S., Ssemakula, G. N., Namakula, J., Kigozi, C. B., Alajo, A., Mpembe, I., \& Mwanga, R. O. M. (2014b). Evaluation of promising orange fleshed sweetpotato genotypes in different agroecological zones of Uganda. International Journal of Agriculture and Crop Sciences, 1312-1321.

Niringiye, C. S., Ssemakula, G. N., Namakula, J., Kigozi, C. B., Alajo, A., Mpembe, I., \& Mwanga, R. O. M. (2014a). Evaluation of promising sweetpotato clones in selected agro-ecological zones of Uganda. Time Journals of Agriculture and Veterinary Sciences, 2(3), 81-88.

Ojiambo, P. S., Ayiecho, O., \& Nyabundi, J. O. (1999). Severity of Alternaria leaf spot and seed infection by Alternaria sesami (Kawamura) Mohanty and Behera, as affected by plant age of sesame (Solanum indicum L.). Journal of Phytopathology, 147, 403-407. https://doi.org/10.1111/j.1439-0434.1999.tb03841.x

Osiru, M., Adipala, E., Olanya, O. M., Lemaga, B., \& Kapinga, R. (2007a). Occurrence and distribution of Alternaria leaf petiole and stem blight in Uganda. Plant Pathology, 6, 112-119. https://doi.org/ 10.3923/ppj.2007.112.119

Osiru, M., Olanya, O. M., Adipala, E., Lamega, B., Kapinga, R., Namanda, S., \& El-Bedewy, R. (2007b). Relationships of Alternaria leaf petiole and stem blight disease to yield of sweetpotato cultivars. African Potato Association Conference Proceedings, Alexandria, Egypt, 7, 141-151.

Osiru, M., Olanya, O. M., Adipala, E., Lemaga, B., \& Kapinga, R. (2009). Stability of sweetpotato cultivars to Alternaria leaf petiole and stem blight disease. Phytopathology, 157, 172-180. https://doi.org/10.1111/ j.1439-0434.2008.01457.x

Payne, R. W., Harding, S. A., Murray, D. A.,Soutar, D. M., Baird, D. B., Glaser, A. I., ... Webstar, R. (2011). The guide to Genstat release 14, Part 2: Statistics. VSN International, Hemel Hempstead, UK.

Purchase, J., Hatting, H., \& van Deventer, C. (2000). Genotype $\times$ environment interaction of winter wheat in South Africa: II. Stability analysis of yield performance. South African Journal of Plant and Soil, 17, 101-107. https://doi.org/10.1080/02571862.2000.10634878

Rotem, J. (1994). The Genus Alternaria: Biology, Epidemiology and Pathogenicity. The American Phytopathological Society, St. Paul, Minnesota, USA.

SAS Institute Inc. (2010). SAS/STAT $T^{\circledR}$ 9.22, User's Guide. SAS Institute Inc., North Carolina, USA.

Shaner, G., \& Finney, E. (1977). The effect of nitrogen fertilization on the expression of slow-mildewing resistance in knox wheat. Phytopathology, 67, 1051-1056. https://doi.org/10.1094/Phyto-67-1051

Shrestha, S. K., Munk, L., \& Mathur, S. B. (2005). Role of weather on Alternaria leaf blight disease and its effects on yield and yield components of Mustard. Nepal Agricultural Research Journal, 6, 62-72. https://doi.org/10.3126/narj.v6i0.3366 
Skoglund, L. G., Gatumba, R. W., \& Kihurani, A. W. (1994). Non-viral foliar pathogens and disorders of sweetpotato in Kenya. International Journal of Pest Management, 39, 452-458. https://doi.org/10.1080/ 09670879309371839

Stathers, T. E., Rees, D., Kabi, S., Mbilinyi, L., Smit, N., Kiozya, H., ... Jeffries, D. (2003). Sweetpotato infestation by Cylas spp. in East Africa: I: Cultivar differences in field infestation and the role of plant factors. International Journal of Pest Management, 49, 131-140. https://doi.org/10.1080/0967087021000 043085

Summuna, B., Gupta, S., \& Sheikh, P. A. (2018). Assessing the disease severity of Alternaria blight of rapeseed-mustard in Jammu Province of $\mathrm{J} \& \mathrm{~K}$ and screening of germplasm against the disease. International Journal of Current Microbiology and Applied Sciences, 7(11), 1299-1310. https://doi.org/10.20546/ ijcmas.2018.711.151

Thomason, W. E., \& Philips, S. B. (2006). Methods to evaluate wheat cultivar testing environments and improve cultivar selection protocols. Field Crops Research, 99, 87-95. https://doi.org/10.1016/j.fcr.2006.03.007

Turyamureeba, G., Mwanga, R. O. M., \& Carey, E. E. (2000). Evaluation of promising sweetpotato genotypes for high altitude, cool, moist agroecologies of Uganda. Uganda Journal of Agricultural Science, 5, 40-42.

van Bruggen, A. H. C. (1984). Sweetpotato stem blight caused by Alternaria sp.: A new disease in Ethiopia. Netherlands Journal of Plant Protection, 90, 155-164. https://doi.org/10.1007/BF02006479

Vloutoglou, I., \& Kalogerakis, S. N. (2000). Effects of inoculum concentration, wetness duration and plant age on development of early blight (Alternaria solani) and on shedding of leaves in tomato plants. Plant Pathology, 49, 339-345. https://doi.org/10.1046/j.1365-3059.2000.00462.x

Yada, B., Tukamuhabwa, P., Alajo, A., \& Mwanga, R. O. M. (2011). Field evaluation of Ugandan sweetpotato germplasm for yield, dry matter and disease resistance. South African Journal of Plant and Soil, 142-146 https://doi.org/10.1080/02571862.2011.10640026

Yada, B., Tukamuhabwa, P., Villordon, A., Alajo, A., \& Mwanga, R. O. M. (2010). An online database of sweetpotato germplasm collection in Uganda. HortScience, 45(1), 152-153. https://doi.org/10.21273/ HORTSCI.45.1.153

Zobel, R. W., Wright, M. J., \& Gauch, H. G. (1988). Statistical analysis of yield trials. Agronomy Journal, 80, 388-393. https://doi.org/10.2134/agronj1988.00021962008000030002x

\section{Appendix A}

Weather data for Namulonge and Kachwekano 2015 to 2016

\begin{tabular}{|c|c|c|c|c|c|c|c|c|}
\hline \multirow{3}{*}{ Season } & \multicolumn{2}{|c|}{ Rainfall total (mm) } & \multicolumn{4}{|c|}{ Temperature range $\left({ }^{\circ} \mathrm{C}\right)$} & \multicolumn{2}{|c|}{$\begin{array}{c}\text { Average Relative } \\
\text { Humidity (\%) }\end{array}$} \\
\hline & \multirow{2}{*}{ Namulonge } & \multirow{2}{*}{ Kachwekano } & \multicolumn{2}{|c|}{ Namulonge } & \multicolumn{2}{|c|}{ Kachwekano } & \multirow{2}{*}{ Namulonge } & \multirow{2}{*}{ Kachwekano } \\
\hline & & & Max & Min & Max & Min & & \\
\hline 2015A (March-July 2015) & 264.6 & 490.3 & $28.7-30.0$ & $16.1-16.8$ & $23.7-25.0$ & $11.4-12.5$ & 70.3 & 77.3 \\
\hline 2015B (September 2015-January 2016) & 566.9 & 367.7 & $27.5-28.4$ & $16.3-16.9$ & $24.0-26.4$ & $10.5-13.5$ & 75.6 & 77.8 \\
\hline 2016A (March-July 2016) & 560.8 & 367.7 & $28.3-30.1$ & $16.1-16.9$ & 24.4-24.7 & $11.3-12.3$ & 75.6 & 80.5 \\
\hline
\end{tabular}

\section{Copyrights}

Copyright for this article is retained by the author(s), with first publication rights granted to the journal.

This is an open-access article distributed under the terms and conditions of the Creative Commons Attribution license (http://creativecommons.org/licenses/by/4.0/). 